\title{
Development of Correlations for Compression Index
}

\author{
Hamza Güllü ${ }^{* 1}$, Hanifi Canakci ${ }^{1}$, Ali Alhashemy ${ }^{1}$ \\ ${ }^{1}$ Department of Civil Engineering, University of Gaziantep, 27310, Gaziantep, Turkey \\ * Corresponding Author (Hamza GULLU) \\ Tel: +90 342317 2433, Fax: +90 342360 1107, E-mail: hgullu@gantep.edu.tr
}

Geliş Tarihi: 29.03.2016; Kabul Tarihi: 29.08.2016

\section{Keywords}

Compression index, Soil index property, Liquid limit, Initial void ratio, Correlation, Foundation settlement.

\begin{abstract}
Compression index is one of the most important properties of soils widely used for estimation of settlement during design of foundations. In particular, for routine test requirements, limited laboratory facilities and preliminary evaluations, various equations are available in the literature to simply estimate the compression index using some soil index properties. However, applicability of these equations is often limited for the interested site due to their establishment from different databases. Thus, it is more realistic way to employ the correlations developed using local data of region, provided that data is available. In this viewpoint, this paper aims to develop correlations for the compression index dependent upon the soil index parameters of natural moisture content, liquid limit and initial void ratio for fine-grained soil of Baghdad city. From the developed correlations, it is obtained that the best estimations of compression index is correlated by liquid limit as single variable, and by liquid limit and initial void ratio as double variable. It is clear that use of the developed correlations is more suitable specifically for Baghdad region for preliminary evaluations of foundation settlement.
\end{abstract}

\section{Zemin Sıkışma İndeksi için Korelasyonların Geliştirilmesi}

Özet

Sıkışma indeksi, temellerin tasarımında oturma hesapları için yaygın olarak kullanılan zeminlerin en önemli özelliklerinden biridir. Özellikle rutin deneyler, sınırı laboratuvar koşulları ve ön

\section{Anahtar kelimeler}

Sıkışma indeksi, Zemin indeks özelliği, Likit limit, Başlangıç boşluk oranı, Korelasyon, Temel oturması. değerlendirmeler için, literatürde zemin indeks özelliklerine bağlı olarak basitçe hesaplanabilen sıkışma indeksi denklemleri mevcuttur. Ancak, bu denklemler değişik verilerden oluşturulduğundan, çoğunlukla ilgilenilen bölge için sınırlı kullanım sunmaktadır. Bu yüzden, bölgeye ait yerel veriler ile (eğer veri mevcutsa) geliştirilen korelasyonları kullanmak en gerçekçi yoldur. Bu doğrultuda, bu çalışmada Bağdat şehrine ait ince daneli zeminler için, zemin indeks özelliklerinden doğal su muhtevası, likit limit ve başlangıç boşluk oranına bağlı olarak sıkışma indeksi denklemlerinin geliştirilmesi amaçlanmıştır. Elde edilen denklemlerden, sıkışma indeksinin tek değişkenli ilişkilerde likit limit ile, ve çok değişkenli ilişkilerde ise likit limit ve başlangıç boşluk oranı ile birlikte kullanıldığında en iyi korelasyonları verdiği bulunmuştır. Geliştirilen korelasyonların temel oturması için yapılacak ön değerlendirmelerde özellikle Bağdat bölgesi için kullanıımasının çok daha uygun olduğu açıktır.

(C) Afyon Kocatepe Üniversitesi

\section{Introduction}

An important phase in the selection and design of an appropriate foundation system of constructions is to evaluate the compressibility characteristics of soil. One of the important characteristics of soil compressibility that has been commonly used in the calculation of consolidation settlement of foundations is the compression index. It has been experimentally determined from oedometer tests in accordance with the procedures described in technical standards in detail (ASTM D2435-11, 2011; ASTM D4186-12, 2012). However, considering the oedometer tests for this purpose from in-situ sampling to testing phase mostly requires a lot of time and becomes cost-prohibitive for the civil engineering projects particularly for the routine test requirements and limited laboratory facilities. This has been a significant concern specifically for small projects (Giasi et al. 2003). Thus, numerous attempts have been made by several researchers to correlate the compression 
index of soil specifically dependent upon some simple index properties that mostly include moisture content, liquid limit, plasticity index, shrinkage index, initial void ratio, etc. A wide collected number of these correlations have been summarized in the past works (Burland, 1990; Giasi et al. 2003; Onyejekwe et al. 2015). The interested readers are referred to the past works for a detailed description. In comparison with the consolidation test, obtaining the soil index properties has the advantages of being relatively inexpensive testing that does not require much time or any complex systems. Therefore, it could be very useful in practice to use the existing empirical correlations of compression index for estimation of settlement. However, due to their developments based on the site-specific data and/or widely sourced data, the available correlations of compression index in the literature could not be always assumed to have a general validity for other regions of local sites (Lav and Ansal 2001; Giasi et al. 2003; Onyejekwe et al. 2015). Alternatively, the best way is to develop the correlations of compression index with the data of local site of the interested region, provided that data is available. In this way, it is the most possible to obtain the realistic results for settlement estimation by means of correlations.

For the issue of concern arised above, this paper aims to develop the correlations of compression index versus soil index properties for the soils of Baghdad city along Tigris River, using its local data. In this viewpoint, it is observed that the correlations for compression index for Baghdad city have not been sufficiently studied up to now. Baghdad is the largest city of Iraq located along the Tigris River including poor soils of alluvial and fluvial deposits in the middle Mesopotamian plain. Due to a wide destroyed during the last decades in the city, an increase demand for new constructions has been expected for settling, infrastructure and industrial facilities within urban planning purposes. Thus, it is believed that the proposed correlations of compression index in this paper could significantly contribute at the estimation of consolidation settlement for foundation design of constructions at the Baghdad region, particularly for preliminary evaluations.

\section{Material and Method}

\subsection{Some available equations for compression index}

It would be useful to review available equations of compression index in literature to understand the independent parameters of compression index as well as their mathematical form. The equations could also be beneficial to compare the developed correlations in this study. In the review of the equations, it is observed that, in most of cases, the compression index (Cc) is expressed by establishment with the single index property, primarily including moisture content $\left(w_{n}\right)$, liquid limit (LL) and initial void ratio $\left(\mathrm{e}_{0}\right)$. This is matching with the observation of past work (Lav and Ansal 2001). Thus, this study will mainly be focused on the derivation of the correlations for the compression index with single parameter using these three basic index soil properties (i.e., i) $C c=f\left(w_{n}\right)$, ii) $C c=f(L L)$, iii) $\left.C c=f\left(e_{0}\right)\right)$. But, it is also included the double parameter using $\mathrm{LL}$ and $\mathrm{e}_{0}$ recommended in some earlier works (i.e., iv) $C c=f\left(e_{0}, L L\right)$ ) (Li and White 1993; Cherubini and Giasi 2000). Table 1 presents some of the equations available in the literature, with their applicability of soils. These equations have already been reviewed for performance comparisons in the past works (Giasi et al. 2003; Onyejekwe et al. 2015). Thus, it can be considered that they indicate a potential that is well correlated with compressibility.

As discussed some of the equations in Table 1, the equation of Terzaghi and Peck (1967) dependent upon the liquid limit among the evaluated correlations was found suitable to propose for blue and varicoloured clays outcropping in the southern part of the Bradanic Foredeep, in a past study 
investigating appropriate correlations in the literature (Giasi et al. 2003). In the study of Onyejekwe et al. (2015), the equation of Azzouz et al. (1976) with liquid limit was found overall best to propose for southeast region of Missouri soils, while the equation of Azzouz et al. (1976) with moisture content was proposed overall best one for other regions of Missouri soils. The findings from the past works (Giasi et al. 2003; Onyejekwe et al. 2015) reveal that the applicability of the multitude equations developed up to now could become questionable for the same site of interested region due to their development of different databases. Thus, as in this study, the most useful way to benefit from the correlations of compression index is to derive self site-specific correlations using local data, as stated earlier.

As can be seen from Table 1, the correlations in the most cases are linear-regression-based, which will be employed in this study, with the independent parameter of index property. The degree of compressibility of clay soils is mostly connected to the size of the surface of solid particles, their mineralogy, stress state and water interaction. Since the index properties, partially or fully, represent this nature of compressibility, they are relatively preferred for estimating compression index in an easily way of determination (Giasi et al. 2003). For the index property of liquid limit, it is reported that the liquid limit is a measure of the quantity of water attracted by the solid particles for a given value of undrained shear strength (AlKhafaji and Andersland 1992). But, it should be emphasized that all Atterberg limits are mostly considered as the representative parameters specifically for the behavior induced mineralogical composition for remolded soil (Skempton 1944) or normally consolidated one (Terzaghi and Peck 1967). In view of stress state, Tsuchida (1999) notes that when consolidating a sample with a pressure much larger than the preconsolidation stress, a good correlation between the liquid limit and compressibility is identified. Here, it is important to give a particular attention that soils having same liquid limit but different plastic and shrinkage limits could result in different compressibility behavior, since the liquid limit cannot be fully representative of plasticity characteristics (Sridharan and Nagaraj 2000). Alternatively, some correlations were developed based on shrinkage and plasticity index (Sridharan and Nagaraj 2000). However, both of them are very limited and not found a wide usage in practice compared to the ones with liquid limit.

As for the initial void ratio being the independent parameter of compression index equations, it is reported that in addition to representation of intrinsic soil properties, it takes geological stress history of soil structure into account, which is very important during the estimation of settlement. This is an important parameter particularly for the definition of initial conditions of undisturbed samples (Giasi et al. 2003). This implies that for the behavior of an undisturbed sample it is necessary to develop the equations based on more than one parameter, in order to take both the initial state and the soil composition into account (Giasi et al. 2003). This could also be a general recommendation for all samples. Thus, the equations using multiple parameters could provide a more accurate estimate of the compression index, in particular based on the parameters of $e_{0}$ and LL (Li and White 1993; Cherubini and Giasi 2000). However, here it is important to inform from the study of Onyejekwe et al. (2015) that the equations of compression index with double independent parameter including the initial void ratio were not found overall best among the investigated equations for the interested site, compared with the equations with single parameter. This clearly indicates the importance of development of self site-specific correlations using local data in order to understand the effect of index properties well.

In this paper, some of the widely considered equations in literature reported in Table 1 have also been compared with the ones derived in this 
paper. The attention has been given to the performances due to correlation coefficient $(R)$ and root mean square error (RMSE) defined by Eq.1, as follows:

$R M S E=\left(\frac{\sum_{i=1}^{N}\left(C c_{\text {meas }}-C c_{\text {est }}\right)^{2}}{N}\right)^{1 / 2}$

$R=\left(\sum_{i=1}^{N}\left(C c_{\text {meas }}\right)^{2}-\frac{\sum_{i=1}^{N}\left(C c_{\text {meas }}-C c_{\text {est }}\right)^{2}}{\sum_{i=1}^{N}\left(C c_{\text {meas }}\right)^{2}}\right)^{0.5}$
$\mathrm{CC}_{\text {est }}=$ the compression index estimated from empirical correlation. It is well known that obtaining lower error with higher correlation is the goal of performance evaluation of correlation. The comparisons clearly help to see whether the available equations (Table 1) could be alternatively proposed for the region. However, it is obvious that it is necessary to compare the results obtained using other equations. This is beyond the scope of the work presented in this paper that remains a topic of performance investigation of available correlations for Baghdad soils in detail to be in a separate work.

where $\mathrm{N}=$ number of data, $\mathrm{CC}_{\text {meas }}=$ the compression index measured directly from laboratory tests and

Table 1. Some of available correlations for compression index

\begin{tabular}{lll}
\hline Equation & Comment & Reference \\
\hline$C c=0.01 w_{n}-0.05$ & All clays & Azzouz et al. (1976) \\
$C c=0.01 w_{n}-0.07549$ & All clays & Rendon-Herrero (1983) \\
$C c=0.007 L L-0.07$ & Remolded clays & Skempton (1944) \\
$C c=0.009 L L-0.09$ & All clays & Terzaghi and Peck (1967) \\
$C c=0.006 L L-0.054$ & All clays with LL<100 & Azzouz et al. (1976) \\
$C c=0.008 L L-0.096$ & All clays & Sridharan and Nagaraj (2000) \\
$C c=0.29 e_{0}-0.0783$ & Inorganic soils & Hough (1957) \\
$C c=0.75 e_{0}-0.375$ & Soils with low plasticity & Sowers (1970) \\
$C c=0.4 e_{0}-0.1$ & All natural soils & Azzouz et al. (1976) \\
$C c=0.156 e_{0}+0.0107$ & All clays & Bowles (1979) \\
$C C=0.00058 L L+0.411 e_{0}-0.156$ & All clays & Al-Khafaji and Andersland
\end{tabular}

\subsection{Data used for development of correlations}

The data used in this study consist of the parameters $\mathrm{Cc}, \mathrm{w}_{\mathrm{n}}, \mathrm{LL}$ and $\mathrm{e}_{0}$ belonging to the testing results of fine-grained soils (clay) of
Baghdad city. The data were obtained from a previous work (Alhashemy, 2015), where it is collected from ANDREA Engineering Testing Laboratory (ANDREA, 2016). The testings of 
oedometer and index property were conducted for the Baghdad city, specifically along the Tigris River for a variety of constructions. As regards the methodology used to obtain the compression index and the index properties of soils, it should be emphasized that all testings were performed under similar conditions and using the same technique. The data used for development of correlations in this study includes the number of 69 samples. However, it is important to note that as the database is updated with more supplied data, the development of correlations should be reconsidered in future. Table 2 summarizes the data in some descriptive statistics of variables. Fig.1 illustrates the data in their frequency histogram with normal distribution curve. As shown from the Fig.1 that the frequencies of correlation parameters mostly follow well with the normal distribution curve. This implies that the database is statistically suitable for correlation considerations.
As for the general description of the soils for the Baghdad city (Alhashemy, 2015), lean to fat silty clay with soft to medium or stiff consistencies and fine-grained mixtures of silt and clay with sand and gravel in alternate thicknesses are mostly encountered at the near surface specifically in the Tigris banks. This stratum is overlying with the medium to dense silty sand and fine gravel layers. In some parts, the coarse-grained layer extends down to $17 \mathrm{~m}-18 \mathrm{~m}$. The groundwater table varies from $0.9 \mathrm{~m}$ to $7 \mathrm{~m}$ within the boundary in different part of city. In accordance with Unified Soil Classification System, the region has the fine grained soils that can be classified as $\mathrm{CH}$ and $\mathrm{CL}$ in both. Plasticity index of soils changes approximately from 14 to 40 . The soils passing the sieve size of $0.075 \mathrm{~mm}$ are in the percentage from $78 \%$ to $96 \%$. The unit weight of soils is in the range that approximately varies from $14 \mathrm{kN} / \mathrm{m}^{3}$ to $17 \mathrm{kN} / \mathrm{m}^{3}$.

Table 2. Data used in the study in some descriptive statistics of variables.

\begin{tabular}{|c|c|c|c|c|}
\hline Parameter & $\mathrm{Cc}$ & $w_{n}$ & $\mathrm{LL}$ & $\mathrm{e}_{0}$ \\
\hline Minimum & 0.12 & 17.1 & 32 & 0.511 \\
\hline Maximum & 0.28 & 30.4 & 62 & 0.883 \\
\hline Mean & 0.19 & 24.1 & 44 & 0.711 \\
\hline Std. Deviation & 0.03 & 3.2 & 6 & 0.085 \\
\hline \multicolumn{5}{|c|}{$\begin{array}{l}\mathrm{Cc}=\text { compression index } \\
\mathrm{w}_{\mathrm{n}}=\text { natural moisture content }(\%) \\
\mathrm{LL}=\text { liquid limit } \\
\mathrm{e}_{0}=\text { initial void ratio }\end{array}$} \\
\hline
\end{tabular}



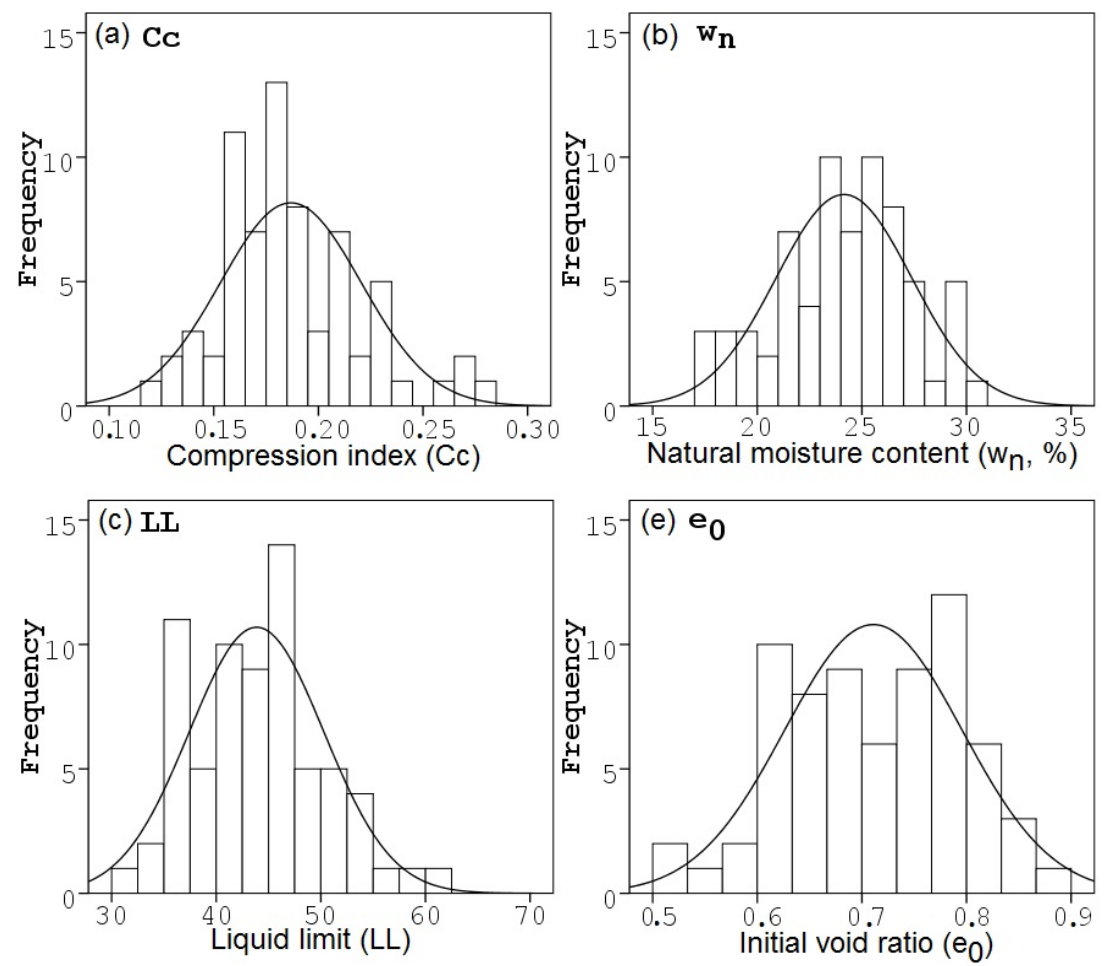

Figure 1. Data used in the study in the frequency histogram.

\section{Results and Discussions}

The developed correlations of Cc in this study separately established with the independent parameters of $w_{n}, L L$ and $e_{0}$ as the single variable correlations and with the parameters $\mathrm{LL}$ and $\mathrm{e}_{0}$ together as the double variable correlation are presented in Table 3. The performances of the developed correlations in RMSE and $\mathrm{R}$ are given in Table 4 comparing with the performances of the available equations (given in Table 1). The performances of the correlations through the estimated $\mathrm{Cc}$ results $\left(\mathrm{CC}_{\text {est }}\right)$ versus laboratory measured $\mathrm{Cc}$ ones ( $\left.\mathrm{CC}_{\text {meas }}\right)$ have been graphically compared in scattering curve by considering the precise of equations in accordance with perfect line (i.e., $\mathrm{y}=\mathrm{x}$ ), as given in Fig.2, regarding the independent parameters of $w_{n}$ (Fig.2a), LL (Fig.2b), $\mathrm{e}_{0}$ (Fig.2c) and $\mathrm{e}_{0}$, LL (Fig.2d).

As shown from the performances of the developed correlations in Table 3, the best estimation of Cc (i.e., lower RMSE with higher R) appears to be obtained with the input inclusion of $\mathrm{LL}$
( $R M S E=0.017, R=0.87$ ) as single variable correlation and with the inputs of $L L$ and $e_{0}$ (RMSE $=0.016$, $\mathrm{R}=0.87$ ) as double variable correlation, in a strong performance. They are followed by the correlations with the input of $w_{n}(R M S E=0.028, R=0.53)$ in a moderate performance and with the input of $e_{0}$ in a poor performance (RMSE $=0.033, \mathrm{R}=0.21$ ). The best estimations indicate that the mineralogical composition of soil only (due the correlation with LL) and/or the mineralogical composition and stress history with together (due to the correlation with $\mathrm{LL}$ and $\mathrm{e}_{0}$ ) become prominent for development of correlations of $\mathrm{Cc}$ for Baghdad soils. This soil behavior on Cc relatively supports the suggestions of earlier works ( $\mathrm{Li}$ and White 1993; Cherubini and Giasi 2000). On the other hand, the stress history of soil only (due to the correlation with $\mathrm{e}_{0}$ ) appears to become weak. This may be attributed to the sampling disturbance prior or during testing. As compared with the past work in the viewpoint of variable performance (Onyejekwe et al. 2015), the performance of the correlation with $\mathrm{LL}$ is found in a good matching as a best estimation. While the correlation with $e_{0}$ and 
LL produces better performance, the correlation with $w_{n}$ performs less. For the correlation with $e_{0}$, similar poor performances are encountered in the past work. On the other hand, a comprehensive study (Tiwari and Ajmera 2012) on the intrinsic consolidation characteristics of soil specimens covering a wide range of activities from highly active to less active clay minerals prepared with consistent initial moisture content found a strong correlation of $\mathrm{Cc}$ with $\mathrm{e}_{0}$. From the comparisons, it can be said that all variations of the performances could be attributed to the fact that the estimations are induced by the site-specific local data due to soil type as well as sampling of testing. Although many researchers starting from Skempton (1944) conducted one dimensional consolidation tests on various natural and reconstituted soil specimens in order to develop correlations between Cc and other index properties of soil, the sample preparation methods used were different (Tiwari and Ajmera 2012).

As for the performance comparison with available equations (Table 4), except the correlation with LL and $e_{0}$, all performances of the developed equations are found similar to the available ones. This similar response was actually expected, because all the compared available equations have been selected on the consideration of having a good estimation potential of $\mathrm{Cc}$ due to the findings in past studies (Giasi et al. 2003; Onyejekwe et al. 2015). At a first sight, the performances may indicate that the available correlations (except AlKhafaji and Andersland 1992) may be alternately proposed for estimation of Cc. However, here it should be emphasized that for final decision of best correlations in the comparisons, some ranking calculations (Cherubini and Orr 2000) that determine accuracy and precise of estimations are recommended. This is a topic of separate investigation. But, in place of ranking evaluations in this study, decision on which correlation is better and/or which available correlation is alternately proposed for the region in place of developed correlations will be made considering the perfect fit (i.e., $y=x$ ) in the scattering plots due to the estimated $\mathrm{Cc}$ results versus laboratory measured $\mathrm{Cc}$ results with respect to the independent parameters (Fig.2).

As shown from Fig.2, all correlations result in different performances that represent the precision of estimation in accordance with the perfect curve (i.e., $y=x$ ). It is well known from a scattering curve (Cherubini and Orr, 2000) that as the data points are accumulated along the perfect curve, the estimation of correlation indicates better fit of performance in a better precision. As concerned with the correlations with the parameter $w_{n}$ (Fig.2a), it is observed that the correlation developed in this study presents better fit of precision with the perfect curve. This is followed by Azzouz et al. (1976) that can be alternately proposed for estimation of $\mathrm{Cc}$ for the region. Regarding the correlations with LL (Fig.2b), it is clear that the correlation developed in this study performs best along the perfect line. This is followed by Azzouz et al. (1976) and then Skempton (1944), which indicate that they can be alternately proposed for estimation of Cc. For the correlations with $\mathrm{e}_{0}$ (Fig.2c), it is observed that all correlations have poor accumulation in precision along the perfect line. Nonetheless, Azzouz et al. (1976) seems to perform better than the others, also including the correlation developed in this study that seems to be not suitable for estimation of Cc. From this, it can be said Azzouz et al. (1976) could be proposed for estimation of $\mathrm{Cc}$ dependent upon the parameter $\mathrm{e}_{0}$. As for the correlations with $\mathrm{LL}$ and $\mathrm{e}_{0}$ (Fig.2d), it is clear that the developed correlation in this study relatively follow best with the perfect curve. Alternately, the scattering of data in Al-Khafaji and Andersland (1992) appears reasonable despite of its low correlation coefficient. As compared with the past work (Onyejekwe et al. 2015), the success of the correlations Azzouz et al. (1976) with $w_{n}$ and with LL discussed the results above seems relatively consistent. Among the correlations between $\mathrm{Cc}$ and liquid limit, it is reported (Tiwari and Ajmera 2012) 
that the correlation Skempton (1944) provides a closer approximation for the low activity soils in comparison to the correlation Terzaghi and Peck's (1967). However, these two correlations are reported to underestimate $\mathrm{Cc}$ for soils having high activity that indicates the importance of the mineralogical composition.

Table 3. Developed correlations of Cc for fine-grained soils (clay) of Baghdad city.

\begin{tabular}{llll}
\hline $\begin{array}{l}\text { Independent } \\
\text { parameter }\end{array}$ & Equation & RMSE & $\mathrm{R}$ \\
\hline $\mathrm{w}_{\mathrm{n}}$ & $C c=0.00553 w_{n}+0.05321$ & 0.028 & 0.53 \\
$\mathrm{LL}$ & $C c=0.00454 L L-0.01246$ & 0.017 & 0.87 \\
$\mathrm{e}_{0}$ & $C c=0.08358 e_{0}+0.12739$ & 0.033 & 0.21 \\
$\mathrm{LL}, \mathrm{e}_{0}$ & $C c=0.004483 L L+0.028871 e_{0}-0.03029$ & 0.016 & 0.87 \\
\hline
\end{tabular}

Table 4. Performances of the developed correlations in this study and available correlations.

\begin{tabular}{llll}
\hline $\begin{array}{l}\text { Independent } \\
\text { parameter }\end{array}$ & Equation & RMSE & $\mathrm{R}$ \\
\hline $\mathrm{w}_{\mathrm{n}}$ & This study & 0.028 & 0.53 \\
& Azzouz et al. (1976) & 0.032 & 0.53 \\
& Rendon-Herrero (1983) & 0.038 & 0.53 \\
\hline $\mathrm{LL}$ & This study & 0.017 & 0.87 \\
& Skempton (1944) & 0.055 & 0.87 \\
& Terzaghi and Peck (1967) & 0.122 & 0.87 \\
& Azzouz et al. (1976) & 0.029 & 0.87 \\
\hline $\mathrm{e}_{0}$ & Sridharan and Nagaraj (2000) & 0.073 & 0.87 \\
& This study & 0.033 & 0.21 \\
& Hough (1957) & 0.069 & 0.21 \\
& Sowers (1970) & 0.071 & 0.21 \\
& Azzouz et al. (1976) & 0.042 & 0.21 \\
\hline LL, e 0 & Bowles (1979) & 0.073 & 0.21 \\
\hline
\end{tabular}


Input parameter of Cc equation

(a) $w_{n}$

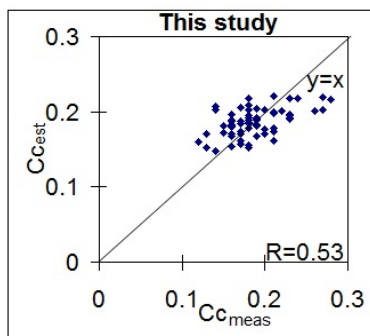

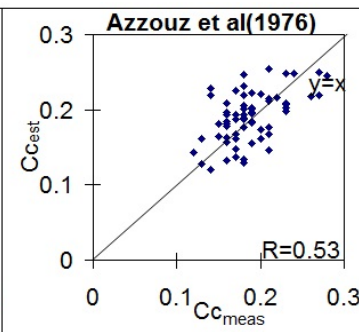

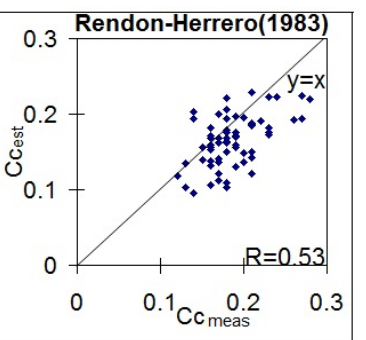

(b) LL
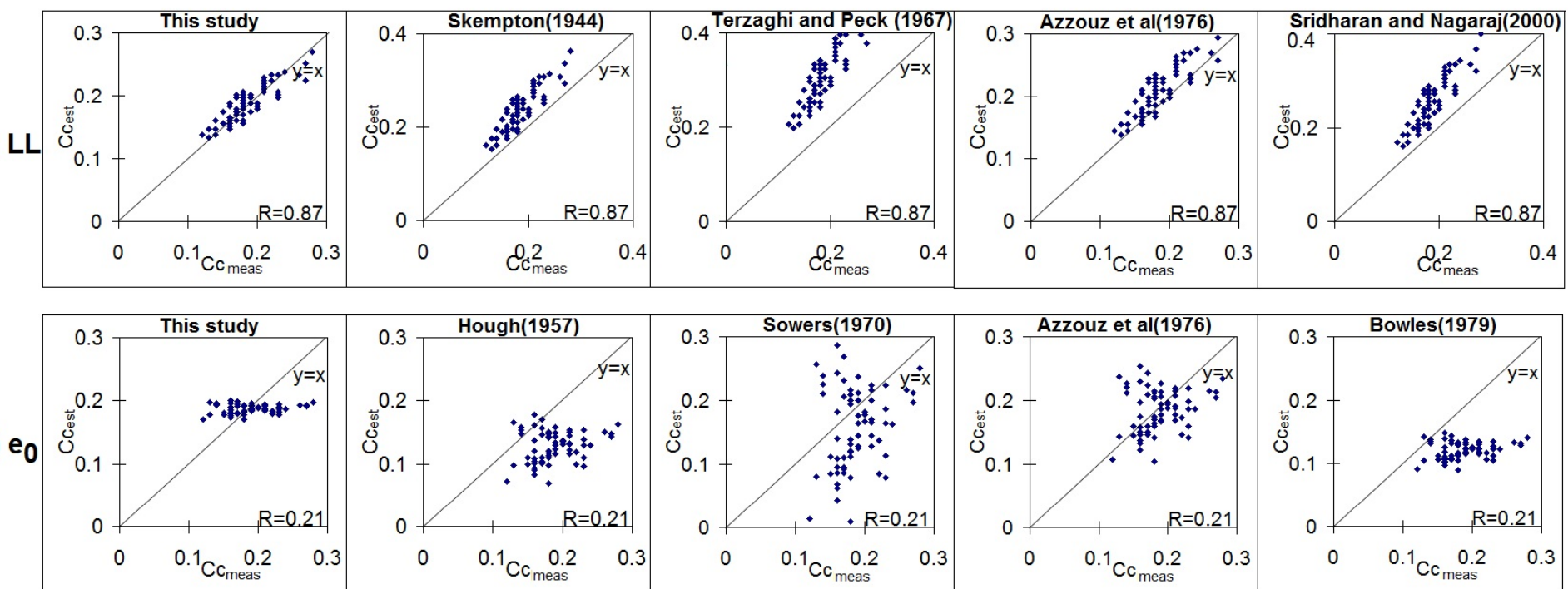

(d) LL, $e_{0}$
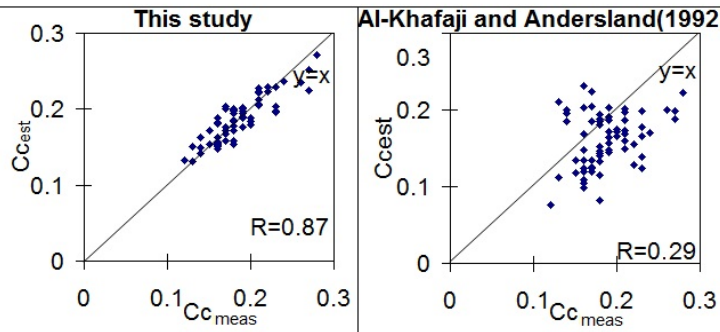
2 Figure 2. Estimated $\mathrm{Cc}$ results $\left(\mathrm{C}_{\mathrm{est}}\right)$ versus laboratory measured $\mathrm{Cc}$ ones $\left(\mathrm{Cc}_{\mathrm{meas}}\right)$, regarding $\mathrm{Cc}$ equation with the independent parameter: a) $\mathrm{w}_{\mathrm{n}}$, 3 b) $L L, c) e_{0}$ and d) $L L, e_{0} . y=x$ indicates perfect fit. 


\section{Conclusions}

A database consisting of 69 data sets containing the consolidation and index parameters of $\mathrm{Cc}, \mathrm{w}_{\mathrm{n}}$, $\mathrm{LL}$ and $\mathrm{e}_{0}$ was used to develop correlations for estimating of compression index for fine-grained soils of Baghdad city. The correlations were developed regarding the independent parameters i) $w_{n}$, ii) $L L$, iii) $e_{0}$ and iv) $L L, e_{0}$ (Table 3 ). The developed correlations have also been compared with the some available correlations in order to understand their performance and alternate usage(Table 4, Fig.2). Based on the findings and observations from the study, the following conclusions could be drawn for estimation of Cc for fine-grained soils of Baghdad city:

1) The best correlations were developed due to the independent parameters with $\mathrm{LL}$ (RMSE=0.017, $\mathrm{R}=0.87$ ) and with $\mathrm{LL}$ and $\mathrm{e}_{0}$ (RMSE=0.016, $R=0.87$ ). They were followed by the correlations with $w_{n}(R M S E=0.028, R=0.53)$ and with $e_{0}(R M S E=0.033, R=0.21)$.

2) All the developed correlations, except the correlation with $\mathrm{LL}$ and $\mathrm{e}_{0}$, are found to show similar performances (RMSE, R) with the available correlations. The performance of the correlation with $L L$ and $e_{0}$ is found better than the one of the available correlation.

3) Based on the performances of RMSE, R together with the precision due to scattering of data along perfect fit (i.e., $y=x$ ), all the developed correlations, except the correlation with $e_{o}$, could be proposed for estimation of Cc.
4) Among the available correlations, the correlation with $w_{n}$ due to Azzouz et al. (1976), the correlations with LL due to Azzouz et al. (1976) and Skempton (1944), the correlation with $\mathrm{e}_{\mathrm{o}}$ due to Azzouz et al. (1976) and the correlation with LL and $e_{0}$ due to Al-Khafaji and Andersland (1992) are found to follow better performance that could be alternately considered for estimation of $\mathrm{Cc}$..

\section{Acknowledgements}

Andrea Engineering Testing Laboratory for supplying the data used in this work is gratefully acknowledged by the authors. The Scientific Research Project Unit of University of Gaziantep offers financial support for this research.

\section{References}

Alhashemy, A., 2015. Geotechnical Properties of Soil around Tigris River in Baghdad. M.Sc. Thesis, Department of Civil Engineering, University of Gaziantep, Gaziantep.

Al-Khafaji, A.W.N. and Andersland, O.B., 1992. Equations for compression index approximation. $J$ Geotech Eng (ASCE), 118(1), 148-153.

ANDREA, 2016. Andrea Engineering Testing Laboratory. Baghdad, Iraq. http://andrealab.com/, Last Access on 25 March 2016.

ASTM D2435/D2435 M-11, 2011. Standard test methods for one dimensional consolidation properties of soils using incremental loading.

ASTM D4186/D4186 M-12, 2012. Standard test method for one dimensional consolidation properties of saturated cohesive soils using controlled-strain loading.

Azzouz, A.S., Krizek, R.J. and Corotis, R.B., 1976. Regression analysis of soil compressibility. Soils Found, 16(2), 19-29. 
Bowles, J.E., 1979. Physical and Geotechnical properties of Soils. McGraw-Hill Book Company, New York.

Burland, J.B., 1990. On the compressibility and shear strength of natural clays. Geotechnique, 40(3), 329378.

Cherubini, C. and Giasi, C.I., 2000. Correlation equations for normal consolidated clays. In: Yokohama IS, Nakase A, Tsuchida T (eds), Proc Int Symp on Coastal Geotechnical Engineering in Practice, AA Balkema, Rotterdam, pp.15-20.

Cherubini, C. and Orr, T.L.L., 2000. A rational procedure for comparing measured and calculated values in geotechnics. In: Yokohama, I.S., Nakase, A., Tsuchida, T. (eds), Proc Int Symp on Coastal Geotechnical Engineering in Practice, AA Balkema, Rotterdam, vol.1, pp 261-265.

Giasi, C.I., Cherubini, C. and Paccapelo, F., 2003. Evaluation of compression index of remolded clays by means of Atterberg limits. Bull Eng Geol Environ, 62(4), 333-340.

Hough, B.K., 1957. Basic Soils Engineering. The Ronald Press Company, New York, pp.114-115.

Lav, M.A.and Ansal, A.M., 2001. Regression analysis of soil compressibility. Turk J Engin Environ Sci, 25, $101-109$.

Li, K.S. and White, W., 1993. Use and misuses of regression analysis and curve fitting in geotechnical engineering. In: Li KS, Lo SCR (eds), Probabilistic methods in geotechnical engineering, AA Balkema, Rotterdam, pp.145-152.

Onyejekwe, S., Xin Kang, X. and Ge, L., 2015. Assessment of empirical equations for the compression index of fine-grained soils in Missouri. Bull Eng Geol Environ, 74, 705-716.

Rendon-Herrero, O., 1983. Universal compression index equation. Closure. J Geotech Eng Div ASCE, 109(5), 755-761.

Skempton, A.W., 1944. Notes on the compressibility of clays. Quarterly Journal of Geological Society of London, 100, 119-135.

Sridharan, A. and Nagaraj, H.B., 2000. Compressibility behavior of remolded, fine-grained soils and correlation with index properties. Can Geotech J, 37, 712-722.

Sowers, G.B., 1970. Introductory Soil Mechanics and Foundations. 3rd edn. The Macmillan Company, Collier-Macmillan Limited, London, p102.

Terzaghi, K. and Peck, R.B., 1967. Soil Mechanics in Engineering Practice. 2nd Edition, John Wiley\&Sons, New York, 729pp.

Tiwari, B. and Ajmera, B., 2012. New correlation equations for compression index of remolded clays. Technical Note. Journal of Geotechnical and Geoenvironmental Engineering, 138(6), 757-762.

Tsuchida, T., 1999. Unified model of e-log $p$ relationship of clay and the interpretation of natural water content of marine deposits. In: Tsuchida T, Nakase IS (eds) Proc Int Symp on Characterization of Soft Marine Clays, AA Balkema, Rotterdam, pp185-202. 